\title{
PENGARUH KEBIJAKAN DIVIDEN TERHADAP HARGA SAHAM
}

\author{
Muhammad Ali Fikri Hakami \\ Department of Management FEB UMM \\ E-mail: santri.njoso@gmail.com
}

\begin{abstract}
The research aim is to analyze the effect of dividend policy on company's stock price. The analysis used Distributed-Lag Regression with Alt and Timbergen Method. The result shows that devident policy has lower contribution on stock price. Dividend on the $t-2$ period has a significant influence on the stock's price, but on the $t-1$ period, and $t-3$ there were no significant effect. The finding indicates that dividend policy has a significant effet on stock price. it means the more dividend increase, stock's price will increase high.
\end{abstract}

Keyword: Dividend Policy, Stock Price, Timbergen Method.

\section{PENDAHULUAN}

Salah satu keputusan penting perusahaan, karena berhubungan dengan pembiayaan perusahaan. Perusahaan harus menetapkan proporsi laba bersih setelah pajak (EAT) antara yang akan dibagikan kepada investor dalam bentuk dividen, atau menahan dalam perusahaan sebagai laba ditahan untuk reinvestasi.

Penentuan besarnya jumlah dividen sampai saat ini ternyata masih merupakan persoalan yang diperdebatkan (kontroversi) di dalam dunia keuangan, apakah dividen memiliki pengaruh terhadap harga saham atau tidak, yang dikenal dengan sebutan teka-teki dividen atau dividend puzzle (Black, 1976 dalam Martin, et.al., 1995:453).

Keown, et.al. (2000:607-608) menjelaskan bahwa sebagian besar kontroversi ini didasarkan pada ketidaksamaan pandangan antara para praktisi dan para akademisi. Martin, et.al. (1995:454) menyebutkan bahwa beberapa praktisi berpengalaman memandang perubahan harga saham dihasilkan oleh pengumuman dividen dan karenanya dividen dianggap penting, sedangkan sebagian besar masyarakat akademis memandang bahwa dividen itu tidak mengandung pengaruh yang berarti terhadap harga saham (irrelevant dividend) karena hubungan antara dividen dan harga saham mungkin hanya merupakan ilusi.

Uraian di atas menjelaskan bahwa ketiga pandangan tersebut bermuara kepada dua arus besar pandangan kebijakan dividen terhadap harga saham perusahaan. Pertama, kebijakan dividen tidak berpengaruh secara signifikan terhadap harga saham perusahaan. Kedua, kebijakan dividen berpengaruh secara signifikan terhadap harga saham perusahaan.

Penelitian tentang pengaruh kebijakan diviiden terhadap harga 
saham (nilai perusahaan) telah banyak dilakukan seperti pada penelitian Harahap (2002), Nurmala (2006), Mardiyati, dkk (2012), dan Permana (2013) yang mendapatkan hasil bahwa kebijakan dividen tidak terbukti berpengaruh secara signifikan terhadap harga saham.

Penelitian yang dilakukan oleh Wijaya (2000), Wijaya (2007), Mayasari (2009), Lotifasari (2010), dan Mahendratama (2012) mendapatkan hasil yang berbeda, yaitu mendapatkan hasil bahwa ternyata kebijakan dividen terbukti berpengaruh secara signifikan terhadap harga saham.

Beberapa hasil penelitian tentang pengaruh kebijakan dividen terhadap harga saham seperti yang diuraikan di atas didapatkan hasil yang tidak konsisten (research gap), sehingga penelitian ini akan menindak lanjuti ketidakkonsistenan pada penelitian sebelumnya. Berdasarkan uraian latar belakang di atas, maka penelitian ini diberi judul "Pengaruh Kebijakan Dividen Terhadap Harga Saham (Pengujian Empiris pada Perusahaan yang Terdaftar di Bursa Efek Indonesia)".

Berdasarkan uraian latar belakang di atas tentang apakah dividen berpengaruh terhadap harga saham atau tidak (dividend puzzle), dan juga hasil penelitian terdahulu yang tidak konsisten (research gap), maka dapat dibuat perumusan masalah "apakah kebijakan dividen berpengaruh secara signifikan terhadap harga saham perusahaanperusahaan yang terdaftar di Bursa Efek Indonesia?".

\section{TINJAUAN PUSTAKA}

Kebijakan dividen (dividend policy) adalah kebijakan yang bersangkutan dengan penentuan pembagian pendapatan (earning) antara penggunaan pendapatan untuk dibayarkan kepada para pemegang saham sebagai dividen atau untuk digunakan dalam perusahaan, yang berarti pendapatan tersebut harus ditanam di dalam perusahaan (Riyanto, 2001:265).

Arti penting perlunya kebijakan dividen menurut Warsono (2003:272) yaitu: (1) kebijakan dividen berpengaruh terhadap sikap investor, (2) kebijakan dividen berdampak pada program pendanaan dan anggaran modal perusahaan, dan (3) kebijakan ini mempengaruhi arus kas perusahaan.

Terdapat tiga teori kebijakan dividen dilihat dari preferensi investor terhadap kebijakan dividen (Brigham dan Houston, 2006:69-72). Pertama, Teori Ketidakrelevanan Dividen (Dividend Irrelavance Theory), yaitu suatu teori yang menyatakan bahwa kebijakan dividen tidak memiliki pengaruh baik terhadap nilai perusahaan maupun biaya modalnya. Miller dan Modigliani (MM) dalam berpendapat bahwa nilai perusahaan hanya ditentukan oleh kemampuan dasarnya untuk menghasilkan laba dan risiko bisnisnya, atau dengan kata lain nilai suatu perusahaan tergantung semata-mata pada pendapatan yang dihasilkan oleh aktivanya, bukan pada bagaimana laba tersebut dibagi antara dividen dan laba ditahan, artinya kebijakan dividen tidak berpengaruh secara signifikan terhadap harga 
saham (nilai perusahaan). Miller dan Modligiani (1961) dalam Martin, et.al. (1995:454-456), membuat dua asumsi untuk menyempurnakan teorinya, yaitu: (1) keputusan-keputusan investasi dan penggunaan utang sudah dibuat dan tidak mempengaruhi besar kecilnya dividen yang akan dibayarkan, dan (2) diasumsikan bahwa pasar modal dalam keadaan sempurna (tidak ada pajak, tidak ada komisi pialang, tidak ada biaya penerbitan saham baru, informasi lengkap, tidak ada konflik keagenan).

Kedua, Teori Burung di Tangan (Bird in The Hand Theory), Gordon dan Lintner menyatakan satu burung di tangan lebih berharga daripada sepuluh burung di udara, artinya dividen dianggap bisa mengurangi ketidakpastian daripada capital gains. Konsekuensinya, harga saham perusahan akan sangat ditentukan oleh besarnya dividen yang dibagikan kepada para pemegang saham, dengan demikian, semakin tinggi dividen yang dibagikan semakin tinggi pula nilai perusahaan.

Ketiga, Teori Perbedaan Pajak (Tax Preference Theory). Teori ini lebih menyoroti dari sisi adanya perbedaan pajak yang dikenakan pada dividen dan capital gains. Menurut teori ini dividen itu sebenarnya merugikan investor. Ditinjau dari segi pajak, capital gains memiliki beberapa keuntungan daripada dividen karena pajak yang dikenakan pada capital gains lebih kecil daripada pajak dividen, selain itu, capital gains juga memiliki keutungan lain yaitu penundaan pembayaran pajak sampai saham terjual, artinya teori ini menjelaskan bahwa para investor lebih menyukai capital gains daripada dividen, sehingga pembayaran dividen yang rendah akan dapat meningkatkan harga saham perusahaan.

Selain ketiga teori atas tiga pandangan dasar kebijakan dividen di atas, Brigham dan Houston (2006:7578) juga menambahkan dua isu teoritis lainnya yang dapat mempengaruhi tentang pandangan terhadap kebijakan dividen. Pertama, Hipotesis Kandungan Informasi atau Pengisyaratan (Signalling Theory). Teori ini berdasarkan asumsi bahwa bahwa manajer mempunyai informasi yang lebih baik mengenai prospek masa depan perusahaan daripada pemegang saham. Teori ini yang menyatakan bahwa investor menganggap perubahan dividen sebagai isyarat dari perkiraan manajemen atas laba, apabila dividen tinggi biasanya menurut para investor merupakan isyarat tentang prospek masa depan perusahaan yang baik. Dividen yang rendah oleh para investor dianggap sebagai sinyal tentang prospek masa depan perusahaan yang tidak baik.

Kedua, Pengaruh Klientele (Clientele Effect Theory). Teori ini menyatakan bahwa kelompok (clientele) pemegang saham yang berbeda akan memiliki preferensi yang berbeda terhadap kebijakan dividen perusahaan. Kelompok pemegang saham yang membutuhkan penghasilan pada saat ini lebih menyukai suatu dividend payout ratio yang tinggi, sebaliknya kelompok pemegang saham yang tidak begitu membutuhkan uang saat ini lebih senang jika perusahaan menahan sebagian besar laba bersih perusahaan untuk reinvestasi.

Proxy dari kebijakan dividen dalam penelitian ini adalah dividend payout ratio (DPR). Alasan DPR 
dipilih sebagai indikator kebijakan dividen dalam penelitian ini karena DPR lebih dapat menggambarkan perilaku oportunistik manajerial yaitu dengan melihat berapa besar keuntungan yang dibagikan kepada shareholders sebagai dividen dan berapa yang disimpan di perusahaan. Dividen yang mengalami peningkatan dan penurunan secara drastis akan berpengaruh langsung terhadap dividend payout ratio (DPR) yang dihasilkan, sehingga investor atau pemegang saham dapat melihat bahwasanya perusahaan sukar untuk diprediksi. Berdasarkan uraian di atas, maka kerangka pikir dalam penelitian ini dapat digambarkan pada Gambar 1:

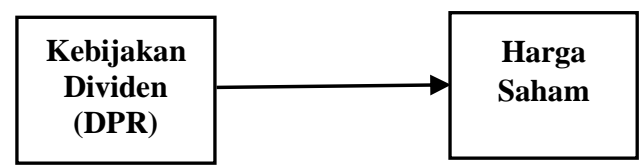

Gambar 1. Kerangka Pikir Penelitian

Gambar di atas menjelaskan bahwa kebijakan dividen yang diproyeksikan dengan DPR berpengaruh secara terhadap harga saham perusahan. Harga saham yang dimaksud dalam penelitian ini adalah harga saham dari saham biasa perusahaan karena harga saham biasa merupakan indikator dari nilai suatu perusahaan, sedangkan harga saham preferen memiliki unsur obligasi dari perusahaan yang merupakan hutang dari perusahaan.

Berdasakan uraian di atas, maka secara teori dapat dirumuskan hipotesis bahwa "kebijakan dividen berpengaruh secara signifikan terhadap harga saham".

\section{METODE PENELITIAN}

Data yang digunakan dalam penelitian ini adalah data yang dikumpulkan, diolah, dan disajikan oleh pihak lain dalam bentuk laporan keuangan (data sekunder). Data dalam penelitian ini diperoleh dari Indonesian Capital Market Directory (ICMD) dan Indonesian Stock Exchange (IDX) yang mempublikasikan ringkasan laporan keuangan tahunan perusahaanperusahaan go public dan diunduh dari internet.

Periode pengambilan data dalam penelitian ini adalah 5 tahun terkahir dari penerbitan laporan keungan tahunan perusahaan yang dipublikasikan, yaitu 2007-2011. Populasi dalam penelitian ini adalah semua perusahaan-perusahaan yang listing di Bursa Efek Indonesia (BEI). Teknik pengambilan sampel dalam penelitian ini dengan menggunakan teknik purposive sampling. Jumlah sampel dalam penelitian ini yang memenuhi kriteria adalah 70 perusahaan.

Variabel dalam penelitian ini adalah kebijakan dividen yang diproyeksikan dengan DPR sebagai variabel bebas, dan harga saham penutupan yang tercatat pada laporan keuangan tahunan perusahaan sebagai variabel terikatnya.

Metode analisis data yang digunakan dalam penelitian ini adalah Regresi Lag yang didistribusikan (Distributed-Lag) yang merupakan selang waktu atau jeda waktu yang diperlukan variabel bebas untuk mempengaruhi variabel tidak bebas (Suharyadi dan Purwanto, S.K, 2004:558). Lag terjadi apabila suatu variabel mempengaruhi variabel tidak bebasnya secara tidak langsung atau ada jeda waktu.

Dalam analisis regresi lag yang didistribusikan ini perlu ditetapkan 
panjang lag optimal. Penentuan panjang lag optimal dapat menggunakan metode dari Alt dan Timbergen (Gujarati dan Porter, 2012:277). Mereka menyarankan prosedur sekuensial (berurutan) untuk mendapatkan lag optimal, yaitu pertama meregresikan $Y_{t}$ pada $X_{t}$, kemudian meregresikan $Y_{t}$ pada $X_{t}$ dan $\mathrm{X}_{(\mathrm{t}-1)}$, kemudian meregresikan $\mathrm{Y}_{\mathrm{t}}$ pada $\mathrm{X}_{\mathrm{t}}, \mathrm{X}_{(\mathrm{t}-1)}$, dan $\mathrm{X}_{(\mathrm{t}-2)}$, dan seterusnya. Prosedur yang berurutan ini berhenti ketika koefisien regresi dari variabel lag menjadi tidak signifikan secara statistik atau koefisien paling sedikit satu variabel bebas berubah tanda dari positif ke negatif atau sebaliknya (Gujarati dan Porter, 2012:277).

Langkah selanutnya adalah menghitung menghitung Koefisien Determinasi $\quad\left(\mathrm{R}^{2}\right) . \quad$ Koefisien Determinasi $\left(\mathrm{R}^{2}\right)$ menunjukkan suatu proporsi dari varian yang dapat diterangkan oleh persamaan regresi terhadap varian total. Besarnya koefisien determinasi dirumuskan sebagai berikut (Suharyadi dan Purwanto, S.K, 2004:514-515).

Terakhir adalah melakukan Uji Hipotes dengan menggunakan Uji $F$ (Uji Simultan) dan Uji t (Uji Parsial).
Uji $F$ dimaksudkan untuk melihat kemampuan menyeluruh dari variabel bebas $\left(\mathrm{X}_{1}, \mathrm{X}_{2}, \mathrm{X}_{3}, \ldots, \mathrm{X}_{\mathrm{k}}\right)$ untuk dapat atau mampu menjelaskan tingkah laku atau keragaman variabel tidak bebas yaitu Y (Suharyadi dan Purwanto, 2004). Sedangkan Uji t dimaksudkan untuk menguji apakah suatu variabel bebas berpengaruh atau tidak terhadap variabel tidak bebas. Uji $t$ yang dilakukan dalam penelitian ini adalah uji t dua sisi karena dalam penelitian ini tidak diketahui kecenderungan kharakteristik dari populasi.

\section{HASIL PENELITIAN DAN PEMBAHASAN}

Total jumlah populasi dalam penelitian sebanyak 484 perusahaan yang terdaftar di Bursa Efek Indonesia (BEI). Sampel pada penelitian ini adalah 70 perusahaan sampel yang memenuhi kriteria-kriteria dari purposive sampling yang telah ditetapkan selama periode penelitian.

Langkah pertama penelitian ini dalam analisis data adalah menentukan panjang lag optimal dengan menggunakan metode Alt dan Timbergen (Prosedur Sekuensial / Berurutan). Tabel 1 merupakan tabel ringkasan hasil regresi lag yang didistribusikan (distributed-lag).

Tabel 1. Hasil Regresi Lag Yang Didistribusikan (Lag-Distributed)

\begin{tabular}{ccc}
\hline No & Nama Regresi & \multicolumn{1}{c}{ Persamaan Regresi } \\
\hline 1 & Tanpa Variabel Lag & $\mathrm{Y}=7010,506+33,206 \mathrm{X}_{\mathrm{t}}$ \\
2 & Dengan Variabel Lag 1 & $\mathrm{Y}=5556,273-8,506 \mathrm{X}_{\mathrm{t}}+94,161 \mathrm{X}_{\mathrm{t}-1}$ \\
3 & Dengan Variabel Lag 2 & $\mathrm{Y}=3762,960-105,627 \mathrm{X}_{\mathrm{t}}+77,099 \mathrm{X}_{\mathrm{t}-1}+$ \\
& & $195,562 \mathrm{X}_{\mathrm{t}-2}$ \\
& & \\
& Dengan Variabel Lag 3 & $\mathrm{Y}=3349,968-262,947 \mathrm{X}_{\mathrm{t}}+150,546 \mathrm{X}_{\mathrm{t}-1}+$ \\
& & $174,546 \mathrm{X}_{\mathrm{t}-2}+150,352 \mathrm{X}_{\mathrm{t}-3}$ \\
5 & Dengan Variabel Lag 4 & $\mathrm{Y}=-10313,544-275,693 \mathrm{X}_{\mathrm{t}}-226,887 \mathrm{X}_{\mathrm{t}-1}+$ \\
& & $843,811 \mathrm{X}_{\mathrm{t}-2}+43,385 \mathrm{X}_{\mathrm{t}-3}+232,953 \mathrm{X}_{\mathrm{t}-4}$ \\
\hline
\end{tabular}


Dari kelima persamaan regresi di atas, maka dapat diketahui bahwa persamaan regresi dengan panjang lag optimal adalah pada persamaan keempat atau regresi dengan variabel lag 3 karena pada persamaan regresi kelima (regresi dengan variabel lag 4 ) koefisien regresinya $\mathrm{X}_{\mathrm{t}-4} \quad\left(\beta_{5}\right)$ mengalami perubahan dari positif menjadi negatif, selain itu konstantanya pun berubah nilai dari positif menjadi negatif, hal ini mengakibatkan konstanta akan sulit diinterpretasikan

Persamaan regresi dengan varibael lag 3, yaitu $\mathrm{Y}=3349,968$ $262,947 \mathrm{X}_{\mathrm{t}}+150,546 \mathrm{X}_{\mathrm{t}-1}+174,546$ $\mathrm{X}_{\mathrm{t}-2}+150,352 \mathrm{X}_{\mathrm{t}-3}$. Persamaan regresi di atas menjelaskan bahwa nilai koefisien $X_{t}\left(\beta_{1}\right)$, artinya menandakan hubungan tak searah apabila dividend payout ratio (DPR) pada periode $\mathrm{t}\left(\mathrm{X}_{\mathrm{t}}\right)$ meningkat, maka harga saham akan menurun, dengan asumsi $\mathrm{X}_{\mathrm{t}-1}, \mathrm{X}_{\mathrm{t}-2}$, dan $\mathrm{X}_{\mathrm{t}-3}$ pada kondisi konstan. Sedangkan nilai positif pada $\beta_{2}, \beta_{3}$, dan $\beta_{4}$ menandakan hubungan searah antara dividend payout ratio (DPR) dan harga saham, dengan asumsi variabel lainnya konstan.

Nilai Koefisien determinasi digunakan untuk mengetahui seberapa besar pengaruh variabel - variabel bebas dalam penelitian dalam mempengaruhi variabel terikatnya. Hasil perhitungan nilai koefisien determinasi dalam penelitian ini dapat dilihat pada Tabel 2 .

Berdasarkan hasil perhitungan regresi diperoleh nilai adjust $\mathrm{R}$ square sebesar 0,082. Hal ini dapat diartikan bahwa sebesar $8.2 \%$ perubahan harga saham dapat dijelaskan oleh dividend payout ratio periode $\mathrm{ke} \mathrm{t}$, dividend payout ratio periode ke $\mathrm{t}-1$, dividend payout ratio periode ke $\mathrm{t}-2$, dan dividend payout ratio t-3, sedangkan sisanya sebesar $91,8 \%$ dijelaskan oleh variabel lain yang tidak dibahas dalam penelitian ini. Sangat terbatasnya variabel $\mathrm{X}$ (DPR) dalam mempengaruhi harga saham karena banyaknya faktor-faktor lain yang mempengaruhi harga saham perusahaan seperti pertumbuhan ekonomi, tingkat inflasi, tingkat suku bunga, kebijakan fiskal, kondisi sosial-politik, tingkat keamanan suatu negara, dan masih banyak faktor lainnya.

Tabel 2. Hasil Koefisien Determinasi

\begin{tabular}{|c|c|c|c|c|}
\hline \multicolumn{5}{|c|}{ Model Summary) } \\
\hline Model & $\mathrm{R}$ & $\begin{array}{c}\mathrm{R} \\
\text { Square }\end{array}$ & $\begin{array}{l}\text { Adjusted } \\
\text { R Square }\end{array}$ & $\begin{array}{c}\text { Std. } \\
\text { of } \\
\text { Esti }\end{array}$ \\
\hline 1 & 32 & 108 & $0,0 \times 2$ & 39796,6 \\
\hline
\end{tabular}

Sumber: Data Diolah

Alasan lain kecilnya nilai keofisien determinasi adalah apabila kita lihat kepemilikan saham perusahaan-perusahaan go public sebagian besar rata-rata dimiliki oleh pihak lain yang merupakan perusahaan juga dan kebanyakan perusahaan dalam naungan perusahaa induk yang sama, seperti PT. Astra Otoparts Tbk. (96.66\% dimiliki PT. Astra International Tbk, publik hanya $4.35 \%$ ), dan hampir sebagian lainnya pun seperti ini.

Uji $F$ ini digunakan untuk menguji secara simultan pengaruh dividend payout ratio (DPR) terhadap harga saham. Hasil dari perhitungan uji F ini disajikan dalam Tabel 3. 
Tabel 3. Hasil Uji Simultan (Uji F)

\begin{tabular}{lccccc}
\hline \multicolumn{1}{c}{ Model } & $\begin{array}{c}\text { Sum of } \\
\text { Squares }\end{array}$ & df & $\begin{array}{c}\text { Mean } \\
\text { Square }\end{array}$ & F & Sig. \\
\hline Regression & 2,597 & 4 & 6,491 & 4,099 & 0,004 \\
Residual & 2,138 & 135 & 1,584 & & \\
Total & 2,398 & 139 & & & \\
\hline
\end{tabular}

Sumber: Lampiran 8

Dari tabel 3 diketahui nilai F_hitung sebesar 4,099 dengan nilai signifikansi 0,004. Sedangkan F_tabel dengan df1 4 dan df2 135 serta taraf signifikansi 0,05 diperoleh F_tabel sebesar 2,4387. Hasil tersebut terlihat bahwa F_hitung $(4,099)>$ F_tabel $(2,4387)$. Berdasarkan hasil tersebut maka dapat disimpulkan bahwa H_0 ditolak yang artinya bahwa variabel bebas (dividend payout ratio) secara simultan berpengaruh signifikan terhadap variabel terikat (harga

periode $\mathrm{t}$ bahwa - $t_{\text {tabel }}$ $2,295) \leq t_{\text {hitung }}(-2,107) \leq t_{\text {tabel }}$ $(2,295)$ yang menandakan $\mathrm{H}_{0}$ diterima dan $\mathrm{H}_{1}$ ditolak, artinya kebijakan dividen yang diproyeksikan dengan DPR terbukti tidak berpengaruh secara signifikan terhadap harga saham.

Uji $t$ untuk periode $t-1$ menunjukkan hasil bahwa - $t_{\text {tabel }}(-$ $2,295) \leq t_{\text {hitung }}(1,069) \geq t_{\text {tabel }}$ $(2,295)$ yang menandakan $\mathrm{H}_{0}$ diterima dan $\mathrm{H}_{1}$ ditolak, artinya kebijakan

Tabel 4. Hasil Uji Parsial (Uji t)

\begin{tabular}{lcccccc}
\hline \multirow{2}{*}{ Model } & \multicolumn{2}{c}{$\begin{array}{c}\text { Unstandardized } \\
\text { Coefficients }\end{array}$} & \multirow{2}{*}{$\begin{array}{c}\text { Standardized } \\
\text { Coefficients } \\
\text { Beta }\end{array}$} & $\mathrm{t}$ & Sig. \\
\cline { 2 - 3 } & $\mathrm{B}$ & Std. Error & & & \\
\hline Constant & 3349,968 & 6595,069 & & 0,058 & 0,612 \\
$\mathrm{X}_{\mathrm{t}}$ & $-262,947$ & 124,805 & $-0,210$ & $-2,107$ & 0,037 \\
$\mathrm{X}_{\mathrm{t}}$ Lag 1 & 150,546 & 140,792 & 0,111 & 1,069 & 0,287 \\
$\mathrm{X}_{\mathrm{t}}$ Lag 2 & 174,546 & 75,476 & 0,203 & 2,313 & 0,022 \\
$\mathrm{X}_{\mathrm{t}}$ Lag 3 & 150,352 & 68,851 & 0,191 & 2,184 & 0,031 \\
\hline
\end{tabular}

Sumber: Lampiran 8

saham) perusahaan-perusahaan di Bursa Efek Indonesia. Hasil uji parsial (uji t) dalam penelitian ini dapat dilihat pada Tabel 4.

Dari tabel 4 dapat diketahui bahwa $t_{\text {hitung }}$ untuk periode $t$ sebesar -2,107, periode t-1 sebesar 1,069, periode $\mathrm{t}-2$ sebesar 2,313, dan periode t-3 sebesar 2,184, sedangkan untuk $t_{\text {tabel }}$ sebesar $\pm 2,295$.

Pengaruh dividend payout ratio (DPR) pada periode $\mathrm{t}$ terhadap harga saham perusahaan-perusahaan di Bursa Efek Indonesia Berdasarkan hasil perhitungan uji t yang disajikan pada Tabel 4 dapat diketahui pada dividen yang diproyeksikan dengan DPR terbukti tidak berpengaruh secara signifikan terhadap harga saham. Sedangkan uji $t$ untuk periode $t-2$ menunjukkan hasil bahwa $t_{\text {hitung }}$ $(2,313)>t_{\text {tabel }}(2,295)$ yang menandakan bahwa $\mathrm{H}_{0}$ ditolak dan $\mathrm{H}_{1}$ diterima, artinya kebijakan dividen yang diproyeksikan dengan DPR terbukti berpengaruh secara signifikan terhadap harga saham. Terakhir adalah uji t untuk periode $\mathrm{t}-3$ dengan hasil $t_{\text {tabel }}(-2,295) \leq t_{\text {hitung }}(2,184) \leq t_{\text {tabel }}$ $(2,295)$ yang menandakan $\mathrm{H}_{0}$ diterima dan $\mathrm{H}_{1}$ ditolak, artinya kebijakan dividen yang diproyeksikan dengan 
DPR terbukti tidak berpengaruh secara signifikan terhadap harga saham.

Hasil uji simultan (uji F) dan uji parsial (uji t) yang menemukan hasil berbeda menjelaskan bahwa ternyata para investor dalam membeli saham perusahaan tidak hanya memperhatikan kebijaka dividen (DPR) pada suatu periode tertentu saja, tetapi para investor, khususnya para investor perorangan lebih memperhatikan catatan historis jumlah pembagian dividen (DPR) suatu perusahaan pada periode-periode sebelumnya, jadi harga saham perusahaan tidak hanya dipengaruhi oleh dividen pada suatu periode tertentu saja, namun juga dipengaruhi oleh catatan historis pembagian dividen (DPR) pada periode-periode sebelumnya.

Hal tersebut dilakukan oleh para investor mungkin sebagai usaha untuk meminimalkan risiko atas ketidakpastian di masa depan, yang didasarkan atas ketidaksamaan kepemilikan informasi yang lengkap antara pihak manajemen dan para investor tentang kondisi perusahaan yang sesungguhnya, seperti dasar munculnya pendekatan isu teoritis pada Teori Pensinyalan atau Pengisyaratan (Signalling Theory). Para investor menganggap bahwa catatan historis pembagian dividen (DPR) yang baik merupakan salah satu sinyal dan informasi tentang minimalnya risiko atas investasi mereka, sehingga diharapkan dapat memberikan keuntungan (return) yang maksimal.

Dari uraian di atas dapat diketahui bahwa sangat tepat menggunakan metode analisis regresi lag yang didistribusikan karena metode analisis ini juga memperhitungkan pengaruh waktu, sehingga sangat tepat para ahli ekonometrika mengungkapkan bahwa dengan adanya metode analisis yang memperhatikan pengaruh waktu (lag) ilmu ekonomi telah menjadi ilmu yang dinamis dari dulunya yang bersifat statis.

Hasil penelitian ini juga menemukan bahwa koefisien regresi $(\beta)$ pada periode ke $\mathrm{t}-1$, periode $\mathrm{t}-2$, dan periode $\mathrm{t}-3$ bernilai positif ( + ) yang menandakan hubungan searah kebijakan dividen terhadap harga saham, artinya apabila kebijakan dividen meningkatkan jumlah pembagian dividennya, maka harga saham akan mengalami peningkatan juga. Hal ini menjelaskan bahwa hasil penelitian ini lebih dominan dan sesuai dengan Teori Satu Burung di Tangan (Bird in The Hand Theory).

Teori Satu Burung di Tangan (Bird in The Hand Theory) menyatakan bahwa pengembalian (return) dalam bentuk dividen lebih disukai oleh para investor daripada pengembalian (return) dalam bentuk capital gains karena dividen dapat mengurangi ketidakpastian atau risiko kerugian atas dana yang mereka tanamkan dalam perusahaan tersebut. Hal ini secara tidak langsung menjelaskan bahwa kebijakan dividen denga dividen yang lebih menarik dan diminati oleh para investor, sehingga akan meningkat permintaan saham perusahaan tersebut, peningkatan permintaan tersebut akan meningkatkan juga harga saham perusahaan tersebut.

Uraian di atas menjelaskan bahwa hasil penelitian sesuai dan mendukung hasil dari penelitian yang dilakukan oleh Wijaya (2000), Wijaya (2007), Lofitasari (2010), dan Wahyu 
Mahendratama (2012) yang juga menemukan bahwa kebijakan dividen berpengaruh secara signifikan terhadap harga saham perusahaan yang artinya mendukung pandangan kerelevanan dividen (dividend relevance) dan menolak pandangan ketidakrelevanan dividen (irrelevance dividend).

\section{SIMPULAN}

Berdasarkan uraian di atas penelitian ini dapat diambil kesimpulan bahwa kebijakan dividen terbukti berpengaruh secara signifikan terhadap harga saham. Hasil penelitian ini juga lebih dominan dan mendekati Teori Burung di Tangan (Bird in The Hand Theory). Hal ini berdasarkan dari hasil analisis regresi lag yang didistribusikan (distributed-lag) dengan variabel lag 3 sebagai panjang lag optimal yang menunjukkan kecenderungan nilai positif (hubungan searah) pada nilai koefisien regresi $\left(\beta_{2}, \beta_{3}\right.$, dan $\left.\beta_{4}\right)$, artinya semakin tinggi dividen yang dibagikan maka akan semakin tinggi harga sahamnya.

\section{DAFTAR PUSTAKA}

Brigham, E. F., dan Houston, J. F. 1998. Fundamentals of Financial Management; Tenth Edition, Thomson SouthWestern. Diterjemahkan oleh Ali Akbar Yulianto. 2006. Penerbit Salemba Empat. Jakarta.

Gujarati, D. N., dan Porter, D. C. 2009. Basic Econometric; Fifth Edition. Mc Graw Hill International Edition. Diterjemahkan oleh Raden Carlos Mangunsong. 2012. Penerbit Salemba Empat. Jakarta.
Harahap, A. M., 2002. Pengaruh Kebijakan Dividen Terhadap Harga Saham: Penelitian Empiris Pada PerusahaanPerusahaan Yang Terdaftar Di Bursa Efek Jakarta. Tesis. Jakarta: Fakultas Ekonomi dan Bisnis Universitas Indonesia.

Keown. A. J., Petty, J. W., Martin, J. D., dan Scott Jr., D. F. 1996. Basic Financial Management; Seventh Edition, Prentice-Hall. Inc.USA. Diterjemahkan oleh Chaerul D. Djakman dan Dwi Sulisyorini. 2000. Penerbit Salemba Empat. Jakarta.

Lofitasari, Herlina. 2010. Pengaruh kebijakan Dividen Terhadap Harga Saham Indeks LQ 45. Skripsi. Malang: Fakultas Ekonomi dan Bisnis UMM.

Mahendratama, Wahyu. 2012. Analisis Pengaruh Kebijakan Dividen Terhadap Harga Saham: Studi Kasus Pada Perusahaan LQ45 Yang Terdaftar Di Bursa Efek Indonesia Periode 2008-2010. Skripsi. Semarang: Fakultas Ekonomi Universitas Negeri Semarang.

Mardiyati, U., Ahmad, G. N., dan Putri, R. 2012. Pengaruh Kebijakan Dividen, Kebijakan Hutang, Dan Profitabilitas Terhadap Nilai Perusahaan Manufaktur Yang Terdaftar Di Bursa Efek Indonesia (BEI) Periode 2005-2010. Jurnal Riset Manajemen Sains Indonesia (JRMSI). 3 (1): 117.

Martin, J. D., Keown. A. J., Petty, J. W., dan Scott Jr., D. F. 1996.Basic Financial Management; Fifth Edition, 
Prentice-Hall. Inc.USA.

Diterjemahkan oleh Haris

Munandar. 1995. Penerbit

Rajawali Press. Jakarta.

Mayasari, Eva. 2009. Pengaruh

Kebijakan Dividen

Terhadap Harga Saham

(Pada Perusahaan Food

and Baverage Yang Go

Public Di Bursa Efek

Indonesia). Skripsi.

Malang: Fakultas Ekonomi dan Bisnis UMM.

Nadhiroh, Umi. 2003. Studi Empiris Keputusan Keputusan Dividen, Investasi, dan Pendanaan Eksternal Pada Perusahaan

- Perusahaan Indonesia

Yang Go Public di Bursa Efek Indonesia. Jurnal OTONOMI. 13 (1): 91.

Nurmala. 2006. Pengaruh

Kebijakan Dividen

Terhadap Harga Saham

Perusahaan-Perusahaan

Otomotif Di Bursa Efek

Jakarta. Jurnal Mandiri. 8

(1): 17-23.

Permana, M. F. D. 2013. Pengaruh

Keputusan Investasi,

Keputusan Pendanaan,

Dan Kebijakan Dividen

Terhadap Nilai Perusahaan

(Studi Kasus Pada

Perusahaan Manufaktur

Yang Tercatat di BEI).

Skripsi. Malang: Fakultas

Ekonomi dan Bisnis

UMM.

Suharyadi dan Purwanto, S. K.

2004.

Metodologi
Penelitian. Gramedia Pustaka. Jakarta.

Warsono. 2003. Manajemen

Keuangan Perusahaan.

Bayumedia Publishing.

Malang.

Weston J. Fred dan Eugene F. Brigham. 1993. Basic

Financial Management;

Edisi Kesembilan.

Diterjemahkan oleh

Alfonsus Sirait. 2001.

Penerbit Erlangga. Jakarta.

Widoatmojo, Sawidji. 2005. Cara

Sehat Investasi di Pasar

Modal. Penerbit PT.

Jurnalindo Aksara Grafika.

Jakarta.

Wijaya, Chandra. 2000. Pengaruh

Kebijakan Dividen

Terhadap Nilai Perusahaan

Di Indonesia: Pengujian

Empiris Berdasarkan

CAPM Pada Perusahaan

Yang Telah Go Public Di

Bursa Efek Jakarta. Tesis.

Bandung: Magister

Manajemen Bisnis dan

Administrasi Teknologi. ITB.

Wijaya, D. A. 2007. Pengaruh

Kebijakan Dividen

Terhadap Harga Saham

Perusahaan Go Public

Yang Tercatat Di Bursa

Efek Jakarta. Skripsi.

Malang: Fakultas Ekonomi dan Bisnis UMM.

http://www.idx.co.id/id/beranda/p ublikasi/ringkasankinerjap erusahaantercatat.aspx diunduh pada tanggal 15 Desember 2013 
